
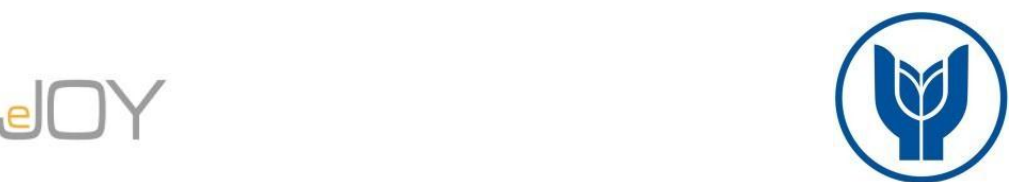

Seçkin, Ş., N. / Journal of Yasar University, 2018, 13/50, 112-124

\title{
Algılanan İş Güvencesizliğí, İçsellik Statüsü ve Örgütsel Sinizm İlişkisinde Örgütsel Desteğin Rolü: İmalat Sektöründe Bir Araştırma
}

\author{
The Role of Organizational Support on Perceived Job Insecurity, Insider Status \\ and Organizational Cynicism Relationship: A Research on Manufacturing \\ Sector
}

Şeyda Nur SEÇKİN, İnönü Üniversitesi, Türkiye, seydaseckin@gmail.com

\begin{abstract}
Öz: Bu çalışmada, algllanan iş güvencesizliği, içsellik statüsü ve örgütsel sinizm iliş̧kisinde örgütsel desteğin rolünün incelenmesi amaçlanmaktadır. Saha araştırması, Malatya ilinde faaliyet gösteren orta ve büyük ölçekli imalat işletmelerinde idari birimlerde görev yapan ve yönetici kadrosunda olmayan personel üzerinde yürütülmüş̧ür. Yapılan literatür taramasında söz konusu değişkenler arasındaki ilişkiyi ele alan herhangi bir çalışmaya rastlanmamış; içsellik statüsü üzerine yapılan saha araştırmalarının da son derece sinırlı olduğu görülmüşür. Elde edilecek bulguların ilgili yazına katkı sağlayabileceği varsayımından hareketle saha araş̧tırmasının yürütülmesine karar verilmiştir. Yapılan analizler sonucunda, algılanan iş güvencesizliğinin içsellik statüsünü negatif; örgütsel sinizmi de pozitif yönde etkilediği; içsellik statüsünün algılanan iş güvencesizliği-örgütsel sinizm iliş̧isinde aractlı rolüne sahip olduğu görülmüş̧ür. Bunun yanı sıra, algılanan örgütsel desteğin düzenleyici etkisinin istatistiki açıdan anlamlı olduğu tespit edilmiştir.
\end{abstract}

Anahtar Sözcükler:Algılanan İş Güvencesizliği, Örgütsel Sinizm, İ̧̧sellik Statüsü, Algllanan Örgütsel Destek

Abstract: In this study, it is aimed to investigate the relationship of perceived job insecurity, insider status and organizational cynicism; and the moderating effect of organizational support on this relationship. Field research was conducted on employees working in administrative units of medium and big sized manufacturing firms operating in Malatya. During theliterature review, it was seen that there does not exist any study exploring the relationship of perceived job insecurity, insider status and organizational cynicism with the moderating role of organizatonal support. Besides, empirical researches on perceived insider status are limited. With the assumption that study findings can make contribution to the relevant area, it was decided to conduct the field research. Study findingshave demonstrated that perceived job insecurity has a negative impact on insider status perception and positive impact on organizational cynicism. Moreover, it was found that perceived job insecurity-organizational cynicism relationship was mediated by perceived insider status and the moderating effect of organizational support was statistically significant.

Keywords: Perceived Job Insecurity, Organizational Cynicism, Insider Status, Perceived Organizational Support

\section{GíRiş}

Artan rekabet baskısı, işletmeleri hem daha yalın ve esnek örgüt yapıları kurmaya hem de daha fazla esnek iş gücü kullanmaya sevk etmekte; dolayısıyla da geçmişte olduğu gibi artık çalışanlara ömür boyu istihdam güvencesi vaad edilememektedir. Bunun yanı sıra, pek çok ülkede artan işsizlik oranları ve şirket küçülmeleri çalışanlarda mevcut işlerinin devamlılığına ilişkin kaygıyı artırarak (De Cuyper vd., 2012, s.770) iş güvencesizliği algısını da tetiklemektedir. Yapılan araştırmalar, algılanan iş güvencesizliğinin çalışanlar nezdinde psikolojik sözleşmenin ihlali olarak değerlendirildiğini (De Witte, 2005; Costa ve Neves, 2017); çalışanlarda işe ve örgüte yönelik pek çok olumsuz tutum ve davranışları da beraberinde getirdiğini göstermektedir. Bu olumsuz tutumlardan birisinin de örgütsel sinizm olduğu düşünülmektedir. Yapılan yerli ve yabancı literatür taramasında algılanan iş güvencesizliği ve örgütsel sinizm ilişkisinde içsellik statüsünün aracılık; örgütsel desteğin de düzenleyici rolünü ele alan herhangi bir çalışmaya rastlanmamıştır. Bunun yanı sıra, içsellik statüsüne ilişkin yapılan ampirik çalışmaların da sınırlı olduğu görülmüş̧ür. Buradan yola çıkarak araştırma konusunun ele alınmasına karar verilmiş ve saha araştırması Malatya ilinde faaliyet gösteren orta ve büyük ölçekli imalat işletmelerinde idari birimlerde görev yapan ve yönetici kadrousunda olmayan personel üzerinde yürütülmüştür. 


\section{KURAMSAL ÇERÇEVE}

\subsection{Algılanan İşGüvencesizliği ve Örgütsel Sinizm}

Algılanan iş güvencesizliği, tehdit altındaki işin devamlılı̆̆ını sürdürmeye ilişkin algılanan güçsüzlük (Greenhalgh ve Rosenblatt, 1984, s.438) veya arzu edilmeyen olası iş kaybına ilişkin duyulan korku veya kaygı (De Witte, 2005, s.1) olarak tanımlanabilir. Çalışanın mevcut iş durumunun gelecekteki akıbetine ilişkin herhangi bir öngörüde bulunamaması ve işinin devamlılı̆̆ üzerinde kontrol duygusundan yoksun olması algılanan iş güvencesizliği kavramının temelini oluşturmaktadır (Greenhalgh ve Rosenblatt, 1984). Algılanan iş güvencesizliği öznel bir değerlendirme olup; aynı statüde ve örgütsel şartlar altında olan çalışanlarda bile kişiden kişiye göre değişebilmektedir (Sverke vd., 2002; De Witte, 2005). Çalışan nezdinde mevcut işin kaybedilme olasılı̆̆ 1 ne kadar yüksekse ve iş kaybı sonucunda ortaya çıkabilecek olumsuzluklar çalışan için ne kadar fazla önem arz ediyorsa, algılanan iş güvencesizliği ve çalışan üzerindeki olumsuz etkisi de o kadar fazla olmaktadır (Klandermans, Hesselink ve Vuuren, 2010).

Yapılan araştırmalar dış denetim odaklılık (Ashford, Lee ve Bobko, 1989; Keim vd., 2014), olumsuz duygulanım (De Witte, 2005) ve düşük temel benlik değerlendirmesinin (Lastad vd., 2014) algılanan iş güvencesizliği ile pozitif yönde ilişkili olduğunu göstermektedir. Her ne kadar algılanan iş güvencesizliği öznel bir yargı olsa da söz konusu yargı salt bireysel faktörlerin etkisiyle gelişmemekte; örgütsel çevreye ilişkin faktörler de önemli rol oynamaktadır (De Witte, 2005, s.2). Örneğin, gelecekte gerçekleşmesi beklenen şirket birleşmeleri, küçülmeler veya yeniden yapılanmalar gibi örgütsel değişimler iş güvencesizliği algısını tetiklemektedir (Ashford, Lee ve Bobko, 1989). Bunun yanı sıra, rol çatışması (Keim vd., 2014), dağıtımsal adaletsizlik (Loi, Lam ve Chan, 2012); rol belirsizliği (Ashford, Lee ve Bobko,1989) de algılanan iş güvencesizliğine pozitif yönde etki etmektedir.

Algılanan iş güvencesizliği, bireyi en az fiili iş kaybı kadar olumsuz yönde etkilemektedir (De Witte, 1999). Ayrıca Greenhalgh ve Rosenblatt'a (1984, s.444) göre, bireyin yaşamında iş ne kadar merkezi bir rol oynuyorsa kişinin algıladığ 1 iş güvencesizliğine ilişkin olumsuz tepkisi de o kadar fazla olmaktadır. İş güvencesizliği algısı yüksek olan çalışanların daha fazla korku, kaygı, gerilim gibi olumsuz duyguları yaşama eğiliminde oldukları ve çalıştıkları kuruma olan güvenlerinin de zayıfladığı görülmektedir (Buonocorea, Russob ve Ferrarac, 2015). Algılanan iş güvencesizliği önemli bir stres faktörü olarak (Probst, 2008); çalışanların iş yaşamları üzerinde sahip olduklarını düşündükleri kontrol duygusunu azaltmakta ve tükenmişliğe de yol açabilmektedir (De Cuyper vd., 2012; Vander Elst vd., 2014). Nitekim, Cheng ve Chan (2008) ve Sverke vd. (2002) meta-analiz sonuçları, algılanan iş güvencesizliğinin hem fiziksel hem de psikolojik sağlığı olumsuz yönde etkilediğini; aynı zamanda da iş tatmini, performans ve örgütsel bağlılıkla da negatif yönde ilişkili olduğunu göstermektedir.

Yapılan araştırmalar, algılanan iş güvencesizliğinin işten ayrılma niyeti (De Witte, 2005; Dekker ve Schaufeli, 1995; Chirumbolo ve Hellgren, 2003; Probst, 2005), örgütsel değişime direnç, psikolojik çekilme (Greenhalgh ve Rosenblatt, 1984) ve devamsızlık (Probst, 2000) ile pozitif; örgütsel bağlılık (Davy, Kinicki ve Scheck, 1991) ile de negatif yönde ilişkili olduğunu göstermektedir. Bunun yanı sıra; Kinnunen ve arkadaşlarının (2000) yürütmüşs oldukları boylamsal araştırma sonuçları da, iş güvencesizliği algısına sahip çalışanların çalışma arkadaşları ve amirleriye olan ilişki kalitelerinin bozulduğuna işaret etmektedir.

Yapılan literatür taramasında algılanan iş güvencesizliğinin bireyin işe ve örgüte yönelik tutum ve davranışlarındaki olumsuz etkisinin psikolojik sözleşme kuramı ile açıklandığı görülmektedir (De Witte, 2005). Psikolojik sözleşme, işgören ve işveren arasındaki karşıllklı yükümlülüklere dair çalışanın inancını (Rousseau, 1989:124) ifade etmekte; algılanan iş güvencesizliği de çalışanlar nezdinde psikolojik sözleşmenin ihlali olarak değerlendirilmektedir (De Witte, 2005, s.4; Costa ve Neves, 2017). Algılanan psikolojik sözleşme ihlali, hem çalışanın örgüte duyduğu güveni azaltmakta hem de bireyin çalışıı̆ı örgüte karşı olumsuz tutumlar geliştirmesine yol açmaktadır (Robinson, 1996). Psikolojik sözleşme ihlali algısı örgütsel sinizmi tetikleyen başıca etmenlerden birisi olduğundan (Andersson, 1996), algılanan iş güvencesizliğinin örgütsel sinizmi pozitif yönde etkileyeceği düşünülmektedir.

Dean ve arkadaşları (1998); örgütsel sinizmi, çalışanların örgütün dürüstlükten yoksun olduğuna dair sahip oldukları inanç; örgüte yönelik besledikleri olumsuz duygular (öfke, utanç, tiksinti, gerilim vb.) ve sergiledikleri eleştirel ve küçümseyici davranışları kapsayan çok boyutlu bir kavram olarak tanımlamaktadır. Örgüte yönelik sinik tutumlar, ahlaki ilkelerin örgüt menfaatleri doğrultusunda ve diğer paydaşların zararına ihlal edildiğine ilişkin çalışanların değerlendirmeleri sonucu ortaya çıkmakta; olumsuz inanç, duygu ve davranış olmak üzere üç şekilde tezahür etmektedir. Algılanan örgütsel adaletsizlik (Chiaburu vd., 2013), işten çıkarma ve küçülmeler (Pugh, Skarlicki ve Passell, 2003); örgütsel politika (Chiaburu vd., 2013), istismarcı yönetim (Ay, 2015) çalışanlarda örgüte yönelik sinik tutumları tetikleyen faktörlerden bazılarıdır. Azalan iş tatmini (Johnson ve O'Leary-Kelly, 2003), örgütsel bağlılık (Abraham, 2000) ve düşük bağlamsal performans (Byrne ve Hochwarter, 2008) ise örgütsel sinizmin olumsuz sonuçları arasında yer almaktadir. 
Yapılan litratür taramasında algılanan iş güvencesizliğinin örgütsel sinizm üzerindeki etkisini ele alan herhangi bir çalışmaya rastlanmamıştır. Çınar, Karcıoğlu ve Aslan'ın (2014) çağrı merkezi çalışanları üzerinde yaptıkları araştırmada; örgütsel sinizm, algılanan iş güvencesizliği ve işten ayrılma niyeti arasında pozitif yönlü bir korelasyon olduğu sonucu elde edilmiş; Brandes'in (2008) yöneticiler üzerinde yaptığ çalışmada ise küçülme sonrası örgütsel sinizmin yöneticilerin işte sergilediği çabayı ne yönde etkilediği ve bu etkide algılanan iş güvencesizliğinin düzenleyici rolü incelenmiştir. Çalışmada, iş güvencesizliği algısı yüksek olan yöneticilerde söz konusu ilişkinin pozitif; iş güvencesizliği algısı düşük olan yöneticilerde ise negatif yönde olduğu tespit edilmiştir. İş güvencesizliği algısının, çalışanların örgüte yönelik sinik tutumlar geliştirmesinde tetikleyici bir rol oynayıp oynamadığını ele alan herhangi bir çalışmaya ise rastlanmamıştır.

Algılanan iş güvencesizliği; çalışanlar nezdinde psikolojik sözleşmenin ihlali olarak değerlendirildiğinden (De Witte, 2005; Costa ve Neves, 2017); iş güvencesizliği algısı arttıkça çalışanlarda örgüte yönelik sinik tutumların gelişebileceği söylenebilir. Nitekim, Andersson (1996) algılanan psikolojik sözleşme ihlallerinin örgütsel sinizmin başlica nedenlerinden birisi olduğuna dikkat çekmekte; sinizmin karşılanmayan beklentiler sonucu ortaya çıktığını ve gelişim gösterdiğini ifade etmektedir. Türk toplumunda belirsizlikten kaçınmanın yüksek olması (Sargut, 2001) ve işten elde edilen gelirin pek çok çalışanın yaşamındaki temel gelir kaynağı olduğu düşünüldüğünde; istihdam güvencesi beklentisinin çalışanlarda yüksek olabileceği; işin gelecekteki devamlılığına ilişkin belirsizlik algılanması halinde de örgüte yönelik hem bilişsel hem duygusal hem de davranışsal sinizmin artabileceği söylenebilir. Buradan hareketle, geliştirilen hipotezler aşağıdaki gibidir:

H1a: Algılanan iş güvencesizliği bilişsel sinizmi pozitif yönde tetikler.

H1b: Algılanan iş güvencesizliği duygusal sinizmi pozitif yönde tetikler.

H1c: Algılanan iş güvencesizliği davranışsal sinizmi pozitif yönde tetikler.

\subsection{Algılanan İş Güvencesizliği ve Örgüsel Sinizm İlişkisinde İçsellik Statüsü Algısının Aracılık Rolü}

İçselllik statüsü, bir kişinin çalıştığı kuruma ilişkin hissetiği aidiyet duygusu (Stamper ve Masterson, 2002) veya örgüt içinde kendine yer edindiğine; kabul gördüğüne ilişkin algısı (Masterson ve Stamper, 2003, s.483) olarak tanımlanabilir. Stamper ve Masterson'a (2002, ss.876-879) göre, içsellik statüsü algısının oluşumunda örgütün çalışanlara sağladığ faydalar ve örgütsel sosyalleşme süreci önemli rol oynamaktadır. Çalışanlara sağlanan faydalar (terfi, kariyer geliştirme programları, bilgi paylaşımı vb.), çalışanlar nezdinde örgüt için önemli olduklarına dair bir algı oluşturmakta; dolayısıyla da çalışanın içsellik statüsü algısını güçlendirmektedir. Örgütsel sosyalleşme sürecinde ise örgüte yeni dahil olan çalışanlara yönelik kullanılan sosyalizasyon strateji ve taktikleri içsellik statüsü algısınının oluşumunda önemli rol oynamaktadır. Stamper ve Masterson (2002:879), çalışanlarda içsellik statüsü algısının oluşumunda örgütsel desteğin bir tür ön koşul olduğunu belirtmekte ancak örgütsel desteğin her zaman için içsellik statüsünü beraberinde getiremeyebileceğinin de altını çizmektedir.

İçsellik statüsüne etki eden faktörlere ilişkin yapılan araştırmalar incelendiğinde; yönetici desteği (Hui, Leek ve Wang, 2015; Lapalme vd., 2009); kararlara katılım (Hui, Lee ve Wang, 2015); yetki devri (Chen ve Aryee, 2007) ve liderüye etkileşiminin (Wang, Chu ve Ni, 2010) içsellik statüsüne pozitif yönde etki eden faktörler olduğu görülmektedir. İçsellik statüsü algısına sahip olan çalışanların kendilerini örgüt için önemli ve değerli çalışanlar olarak algıladığı; dolayısıyla da örgüte ve işe yönelik olumlu tutum ve davranışlar sergiledikleri (Knapp, Smith ve Sprinkle, 2014, ss.274275) dile getirilmektedir. İçsellik statüsünün ardıllarına ilişkin yapılan araştırma sonuçlarına bakıldığında ise; içsellik statüsünün iş tatmini (Chen ve Aryee, 2007; Knapp, Smith ve Sprinkle, 2014); örgütsel bağl1lık (Chen ve Aryee, 2007; Lapalme vd., 2009); örgütsel vatandaşlık (Stamper ve Masterson, 2002; Özdevecioğlu ve Balc1, 2011), görev performans1 (Chen ve Aryee, 2007; Wang ve Kim, 2013) ile pozitif; işten ayrilma niyeti (Armstrong-Stassen ve Schlosser, 2011; Knapp vd., 2014) ile de negatif yönde ilişkili olduğu görülmektedir.

Algılanan iş güvencesizliği çalışanlar nezdinde psikolojik sözleşmenin ihlali olarak değerlendirildiğinden (De Witte, 2005; Costa ve Neves, 2017) algılanan iş güvencesizliği arttıkça; çalışanın örgüte yönelik hayal kırıklı̆̆ı kızgınlık, güvensizlik gibi olumsuz duygularının da artacağı; dolayısıyla da örgüte yönelik aidiyet duygusunun zayıflayacağı söylenebilir. Ayrıca, algılanan iş güvencesizliğinin, çalışan nezdinde örgüt içinde kendine tam anlamıyla kalıcı bir yer edinemediğinin ve örgüt için değerli bir çalışan olmadığının bir göstergesi olarak yorumlanabileceği; bu durumun da çalışanın içsellik statüsü algısını zayıflatacağı ifade edilebilir. Çalışanın kuruma karşı hissettiği aidiyet duygusunun zayıflaması bir diğer ifadeyle içsellik statüsünün azalması, esasında çalışan-örgüt ilişki kalitesinin de zayıflaması anlamına gelmektedir. Algılanan içsellik statüsü azaldıkça çalışanın artık kendisini çalıştığı kurumun bir parçası olarak değil de dışsal olarak konumlandıracağı dolayısıyla da sinik tutum ve davranışlar sergileme eğilimi gösterebileceği düşünülebilir. Dolayısıyla; algılanan iş güvencesizliği arttıkça algılanan içsellik statüsünin azalacağı; içsellik statüsü algısının azalmasıyla birlikte de sinik tutum ve davranışlar sergileme eğiliminin görülebileceği düşünülebilir. Buradan yola çıkarak geliştirilen hipotezler aşağıdaki gibidir: 
H2: Algıllanan iş güvencesizliği, içsellik statüsünü negatif yönde etkiler.

H3a: İçsellik statüsü, algılanan iş güvencesizliği ve bilişsel sinizm arasında aracılık etkisine sahiptir.

H3b: İçsellik statüsü, algılanan iş güvencesizliği ve duygusal sinizm arasında aracılık etkisine sahiptir.

H3c: İ̧̧sellik statüsü, algılanan iş güvencesizliği ve davranışsal sinizm arasında aracılık etkisine sahiptir.

\subsection{Algılanan İ̧̧ Güvencesizliği, İ̧̧sellik Statüsü ve Örgütsel Sinizm İlişkisinde Örgütsel Desteğin Düzenleyici Rolï}

Algılanan örgütsel destek; çalışanın örgüte yapmış olduğu katkıların örgüt nezdinde kabul ve takdir gördüğüne; örgütün iyilik ve mutluluğunu dikkate aldığına ilişkin inancı olarak tanımlanabilir (Eisenberger vd., 1986; Rhoades ve Eisenberger, 2002). Blau'nun (1964) Sosyal Mübadele Kuramı ve Gouldner'ın (1960) Karşıllıklılık İlkesi uyarınca; örgütsel destek algısı yüksek olan çalışanlar, örgüte yönelik olumlu tutum ve davranışlar sergilemekte ve örgütten aldıkları destek karşılığında da örgüte gönüllü olarak daha fazla katkıda bulunma eğilimi göstermektedir. Bunun yanı sıra; algılanan örgütsel destek, çalışanlarda onaylanma, saygınlık, bağlanma gibi bir takım sosyo-duygusal ihtiyaçları da önemli ölçüde karşıladığından çalışanlar örgüt üyeliğini öz-kimlikleri kapsamında içselleştirmekte ve örgütle kendileri arasında duygusal bir bağ kurmaktadırlar (Eisenberger vd., 1986). Rhoades ve Eisenberger'in (2002) yapmış oldukları meta-analiz sonuçlarına göre; örgütsel adalet, yönetici desteği ve insan kaynakları uygulamaları örgütsel destek algıSı üzerinde belirleyici bir rol oynamakta; algılanan örgütsel destek arttıkça duygusal bağlılık, iş tatmini ve işte kalma niyeti de artmaktadır. Bunun yanı sıra, algılanan örgütsel desteğin iş-yaşam dengesi, örgüt temelli özsaygı, görev performansı ve örgütsel vatandaşlığ pozitif; tükenmişlik, devamsızlık, iş stresi ve iş-aile çatışmasını da negatif yönde etkilediği görülmektedir (Kurtessis vd., 2017).

Algılanan örgütsel destek, çalışanların içsellik statüsü algısını (Stamper ve Masterson, 2002) ve örgüte yönelik tutum ve davranışlarını olumlu yönde etkilediğinden (Eisenberger vd., 1986); iş güvencesizliğinin içsellik statüsü üzerindeki olumsuz etkisinin çalışanın algıladığı örgütsel destek düzeyine göre değişebileceği ifade edilebilir. İş güvencesizliği algısına sahip olan ancak örgütten yüksek düzeyde destek gördügünü düşünen çalışanlarda; algıllanan iş güvencesizliğinin içsellik statüsü üzerindeki olumsuz etkisinin daha az olacağı; örgütten düşük düzeyde destek gördüğünü düşünen çalışanlarda ise bu etkinin daha fazla olacağı söylenebilir. Buradan yola çıkarak geliştirilen hipotez aşağıdaki gibidir:

H4: Algılanan örgütsel destek, algılanan iş güvencesizliği ve içsellik statüsü arasında düzenleyici rol oynar.

Bunun yanı sıra, algılanan örgütsel desteğin iş güvencesizliği algısı ve örgütsel sinizm ilişkisinde de düzenleyici bir rol oynayabileceği düşünülmektedir. Bir çalışanın hali hazırdaki içsellik statüsü algısı ne düzeyde olursa olsun; algıladığı iş güvencesizliği arttıkça, yaşadığ iş güvencesizliğini psikolojik sözleşme ihlali olarak değerlendireceği (De Witte, 2005; Costa ve Neves, 2017); dolayısıyla da sinik duygu, tutum ve davranışlar sergileme eğiliminde olacağı söylenebilir. Ancak bu eğilimin çalışanın algıladığı örgütsel destek düzeyine göre farklılaşacağı beklenmektedir. İş güvencesizliği algısına sahip olan ancak örgütten yüksek düzeyde destek aldığını düşünen bir çalışanda örgüte yönelik daha az sinik duygu, tutum ve davranış eğilimi görüleceği; aksi takdirde ise bu eğilimin artacağı ifade edilebilir. Buradan hareketle geliştirilen hipotezler aşağıdaki gibidir:

H5a:Algılanan örgütsel destek, algılanan iş güvencesizliği ve bilişsel sinizm arasında düzenleyici rol oynar. H5b:Algılanan örgütsel destek, algıllanan iş güvencesizliği ve duygusal sinizm arasında düzenleyici rol oynar. H5c:Algılanan örgütsel destek, algılanan iş güvencesizliği ve davranışsal sinizm arasında düzenleyici rol oynar.

Kuram ve araştırma bulgularından yola çıkarak geliştirilen araştırma modeli Şekil 1'de yer almaktadır:

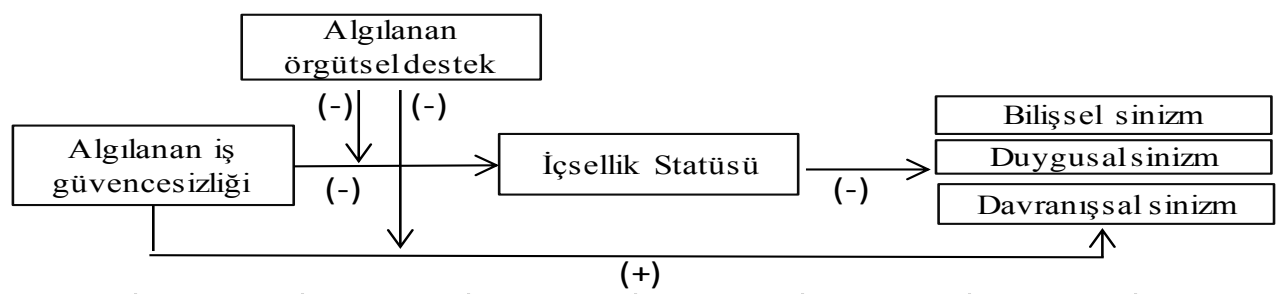

Şekil 1: Araştırma Modeli 


\section{YÖNTEM}

\section{1. Örneklem}

Saha araştırması; Malatya ilinde faaliyet gösteren orta ve büyük ölçekli imalat işletmelerinde idari birimlerde görev yapan ve yönetici kadrosunda olmayan 250 personel üzerinde yürütülmüştür. Türkiye İstatistik Kurumu 2011 yılı iş kayıtlarına göre, çalışan sayısı açısından Malatya ilinde imalat sektöründe faaliyet gösteren orta ölçekli işletme sayısı 36; büyük ölçekli işletme sayısı ise 7'dir. Malatya Ticaret ve Sanayi Odası'ndan edinilen bilgiler doğrultusunda 27 orta ölçekli; 5 büyük ölçekli işletmeye ulaşılmış; kolayda örneklem yöntemi ve bırak-topla tekniği kullanılarak 272 katılımcıdan geri dönüş sağlanmıştır.Ancak anketlerin bir kısmının eksik veya hatalı doldurulması sebebiyle 22 adet anket elenmiştir. Orta ölçekli işletmelerden 148; büyük ölçekli işletmelerden 102; toplamda 250 adet anket değerlendirmeye alınmıştır.Elde edilen veriler, güvenilirlik, doğrulayıcı faktör analizi, korelasyon ve regresyon analizleri yapılarak incelenmiş; araştrma hipotezleri PROCESS Macro 2.16 kullanılarak test edilmiştir.

Örnekleme ilişkin tanımlayıcı istatistiklere baktığımızda; katılımcıların \%12,4'ünün 20-25; \%46,4'ünün de 26-34 yaş aralığında olduğu görülmektedir. Bir diğer ifadeyle, katılımcıların yarıdan fazlasının $(\% 58,8) 35$ yaşın altında olduğu ifade edilebilir. 35-49 yaş aralığında olan katılımcıların oranı \%34 iken; 50 yaş ve üstü olan katılımcıların oranı ise sadece \%7,2'dir. Katılımcıların yarıdan fazlası erkek (\%59,6) ve evlidir (\%64,8). \%12,8'i lise; 48,8'i ön lisans; \%32,8'i lisans; \%5,6'sı da lisansüstü mezunu olduğunu belirtmiştir. Katılımcıların çalışma sürelerine baktığımızda ise \%19,6'sının 3 yıldan az; \%48,4'ünün 3-8 yıl; \%20,4'ünün de 9-14 yıldır mevcut işlerinde çalıştıkları görülmektedir. Mevcut işyerlerinde çalışma süresi 15 yıl ve üzeri olan katılımcıların oranı ise \%11,6'dır. Sektörel açıdan dağılıma baktığımızda katılımcıların\%75,6'sı gıda; \%24,4'ü de tekstil sektöründe çalıştığını belrimiştir. Örnekleme ilişkin genel bir betimleme yapılacak olursa, katılımcıların büyük bir çoğunluğunun ön lisans ve lisans mezunu olduğu $(\% 81,6)$; gıda sektöründe çalıştığı; yarıdan fazlasının erkek; evli ve mevcut işyerlerinde maksimum 8 yıldır çalıştığı ifade edilebilir.

\subsection{Kullantlan Ölçekler}

Algılanan iş güvencesizliğinin ölçümünde Probst (1998) tarafından geliştirilen iş güvencesi endeksi kullanılmıştır. Ölçeğin Türkçeye uyarlaması Önder ve Wasti (2002) tarafından yapılmış; Türkiye örnekleminde geçerli ve güvenilir olduğu belirlenmiştir. Ölçeğe ilişkin örnek maddeler; "Çalıştığım kurumda geleceğimi tahmin etmek zor", "Çalıştı̆̆ım kurumda gelecekteki istihdam durumum belirsiz" şeklindedir. Örgütsel sinizm için ise Brandes, Dharwadkar ve Dean (1999) tarafindan geliştirilen 3 boyutlu toplam 13 maddeden oluşan (bilişsel sinizm 5 madde; duygusal sinizm 4 madde; davranışsal sinizm 4 madde) örgütsel sinizm ölçeği kullanılmıştır. Ölçeğin Türkçe formunun geçerlilik ve güvenilirlik çalışması Karacaoğlu ve İnce (2012) tarafından yapılmıştır (Örnek maddeler; bilişsel sinizm: "Çalıştığım işletmenin politika, amaç ve uygulamaları arasında çok az ortak yön vardır; duygusal sinizm: "Çalıştı̆̆ım işletmeyi düşündükçe gerilirim"; davranışsal sinizm: "Çalıştığım işletme dışındaki arkadaşlarıma, işte olup bitenler konusunda yakınırım”). Algılanan örgütsel desteğin ölçümünde Eisenberger ve arkadaşları (1986) tarafından geliştirilen örgütsel destek ölçeğinin kısa formu (Örnek madde: "Çalıştı̆̆ım kurum düşüncelerime önem verir"); içsellik statüsü için de Stamper ve Masterson'ın (2002) geliştirmiş olduğu 6 madde ve tek boyuttan oluşan ölçek kullanılmıştır (Örnek madde: “Kendimi çalıştığım kurumun bir parçası gibi hissediyorum"). Örgütsel destek ölçeğinin Türkiye örnekleminde geçerlilik ve güvenilirlilik çalışması Giray ve Şahin (2012) tarafından yapılmıştır. Algılanan içsellik statüsü ölçeği ise daha öncesinde Türkçeye çevrilmiş; Türkiye örnekleminde geçerli ve güvenilir olduğu belirlenmiştir (Örn. Mirap, 2008; Köksal, 2012; Çakal ve Özdemir, 2016). Kullanılan ölçekler 5 noktalı Likert tipi olup yanıtlar $1=$ Kesinlikle Katılmıyorum ve 5=Kesinlikle Katılıyorum aralığında derecelendirilmiştir.

Yapılan doğrulayıcı faktör analizi sonucunda algılanan iş güvencesizliği ölçeğinin ki-kare istatistiğinin serbestlik derecesine oranı ( $\chi 2 / \mathrm{df})$ 1,925; kök ortalama kare yaklaşım hatası (RMSEA) 0,061; Tucker-Lewis indeks (TLI) değeri 0,995 ve karşılaştırmalı uyum indeks (CFI) değeri de 0,998 olarak bulunmuştur. İçsellik statüsü ve algılanan örgütsel destek ölçeklerine ilişkin elde edilen değerler ise sırasıyla; içsellik statüsü için $\chi 2 / \mathrm{df}=2,003$; RMSEA=0,063; TLI=0,985 ve $\mathrm{CFI}=0,992$; algılanan örgütsel destek için de $\chi 2 / \mathrm{df}=1,998$; RMSEA=0,071; TLI=0,982 ve CFI=0,994'dür. Örgütsel sinizm ölçeğinin alt boyutlarına ilişkin uyum indeks değerleri ise kabul edilebilir sınırlar içerisindedir [(bilişsel sinizm: $\chi 2 / \mathrm{df}=1,658 ; \mathrm{RMSEA}=0,058 ; \mathrm{TLI}=0,996 ; \mathrm{CFI}=0,998$ ); (duygusal sinizm: $\chi 2 / \mathrm{df}=2,289 ; \mathrm{RMSEA}=0,074 ;$ TLI=0,975; $\mathrm{CFI}=0,984)$; (davranışsal sinizm: $\chi 2 / \mathrm{df}=2,271 ; \mathrm{RMSEA}=0,072 ; \mathrm{TLI}=0,951 ; \mathrm{CFI}=0,992)]$. Elde edilen sonuçlar, kullanılan ölçeklerin faktör yapılarının yeterli uyum değerlerini sağladığını göstermektedir. Kullanılan ölçeklere ilişkin Cronbach $\alpha$ değerleri ise; algılanan iş güvencesizliği için 0,984; içsellik statüsü için 0,891; algılanan örgütsel destek için de 0,927'dir. Örgütsel sinizmin alt boyutlarına ilişkin Cronbach $\alpha$ değerleri de bilişsel sinizm için 0,923; duygusal sinizm için 0,965; davranışsal sinizm için de 0,825 olarak bulunmuştur. 


\subsection{Bulgular}

Araştırma hipotezlerinin test edilmesine geçmeden önce araştırmanın ölçüm modeli ve oluşturulan alternatif modeller doğrulayıcı faktör analizi ile test edilmiş; ölçüm modeli $\chi 2$ fark testi uygulanarak alternatif modellerle karşılaştırılmıştır. Altı faktörlü mevcut araştırma modeli Model 1; içsellik statüsü ve algılanan örgütsel desteğin tek bir faktör olarak ele alındığı Model 2; örgütsel sinizm alt boyutlarının tek bir faktör altında toplandığı Model 3; algılanan örgütsel destek ve içsellik statüsünün tek faktör olarak ele alındığı ve örgütsel sinizmin de tek boyut olarak analize dahil edildiği Model 4 ve son olarak tüm değişkenlerin tek faktör altında toplandığ Model 5 doğrulayıcı faktör analiziyle test edilmiştir. Elde edilen sonuçlar Tablo 1'de yer almaktadır:

Tablo 1. Alternatif Ölçüm Modellerine İlişkin Uyum İndeksleri

\begin{tabular}{lccccccc}
\hline Model & $\chi 2(\mathrm{df})$ & RMSEA & TLI & GFI & CFI & $\Delta \chi 2(\mathrm{df})$ & $\mathrm{p}$ \\
\hline Model 1, 6 faktör $^{\mathrm{a}}$ & $505,84(240)$ & 0,071 & 0,932 & 0,849 & 0,956 & & \\
Model 2, 5 faktör $^{\mathrm{b}}$ & $1832,63(246)$ & 0,161 & 0,719 & 0,588 & 0,750 & $1326,79(6)$ & $\leq 0,01$ \\
Model 3, 4 faktör $^{\mathrm{c}}$ & $726,89(248)$ & 0,097 & 0,898 & 0,817 & 0,920 & $221,05(8)$ & $\leq 0,01$ \\
Model 4, 3 faktör $^{\mathrm{d}}$ & $1954,86(249)$ & 0,166 & 0,702 & 0,561 & 0,731 & $1449,02(9)$ & $\leq 0,01$ \\
Model 5, 1 faktör $^{\mathrm{e}}$ & $3262,34(252)$ & 0,219 & 0,480 & 0,437 & 0,525 & $2756.5(12)$ & $\leq 0,01$ \\
\hline
\end{tabular}

$\chi 2 / \mathrm{df}=$ ki-kare istatistiğinin serbestlik derecesine oranı; RMSEA=kök ortalama kare yaklaşım hatası; TLI= Tucker-Lewis indeks ; CFI= karşılaştırmalı uyum indeksi; GFI=iyilik uyum indeksi

${ }^{a}$ Ölçüm modeli

b İçsellik statüsü ve algılanan örgütsel desteğin tek faktör altında toplandığı model

c Bilişsel, duygusal ve davranışsal sinizmin tek faktör altında toplandığı model

d İçsellik statüsü ve örgütsel desteğin tek faktör; örgütsel sinizm alt boyutlarının da tek faktör altında ele alındığı model

e Bütün değişkenlerin tek faktör altında toplandığı model

Tablo 1'de yer alan sonuçlar incelendiğinde, araştırmanın ölçüm modelinin alternatif modellere kıyasla en iyi uyum iyiliği indeks değerlerine sahip olduğu görülmektedir. Elde edilen değerler kabul edilebilir sinırlar içerisinde yer almaktadır (Kabul edilebilir düzeydeki uyum indeks değerleri: $\chi 2$ df $\leq 4-5$; RMSEA=0,06-0,08; TLI=0,90-0,95; $\mathrm{GFI}=0,85-0,89$; CFI $\geq 0,95$; Meydan ve Şeşen, 2015:37). Yapılan $\chi 2$ fark test sonuçları da, ölçüm modelinin diğer modellere kıyasla daha iyi uyum sağladığını; bir diğer ifadeyle, tüm değişkenlerin birbirinden ayrıştığını ve analize ayrı ayrı dahil edilebileceğini göstermiştir ( $\mathrm{p} \leq 0,01$ anlamlılık düzeyinde).

Değişkenlere ilişkin aritmetik ortalama, standart sapma değerleri ile korelasyon katsayıları Tablo 2'de yer almaktadır:

Tablo 2. Değişkenlere İlişkin Tanımlayıcı İstatistikler ve Korelasyon Katsayıları

\begin{tabular}{|c|c|c|c|c|c|c|c|c|}
\hline Değişkenler & Ort. & SS & 1 & 2 & 3 & 4 & 5 & 6 \\
\hline 1.Algılanan iş güvencesizliği & 3,046 & 1,336 & - & & & & & \\
\hline 2.İçsellik statüsü & 3,347 & 1,026 &,$- 678 * *$ & - & & & & \\
\hline 3.Bilişsel sinizm & 3,296 & 1,071 &, $644 * *$ &,$- 613 * *$ & - & & & \\
\hline 4.Duygusal sinizm & 2,539 & 1,198 & $492 * *$ &,$- 670 * *$ &, $576 * *$ & - & & \\
\hline 5.Davranışsal sinizm & 3,056 & 0,953 &, $418 * *$ &,$- 422 * *$ &, $422 * *$ &, $411 * *$ & - & \\
\hline 6.Alg1lanan örgütsel destek & 2,953 & 1,012 &,$- 664 * *$ &, $704 * *$ &,$- 814 * *$ &,$- 604 * *$ &,$- 398 * *$ & - \\
\hline
\end{tabular}

** $\mathrm{p}<0,01 ; * \mathrm{p}<0,05$

Tablo 2'de yer alan aritmetik ortalamalara baktığımızda, katılımcıların algıladıkları iş güvencesizliği, örgütsel destek, içsellik statüsü ile bilişsel ve davranışsal sinizm düzeylerinin orta seviyelerde olduğu söylenebilir. Örgütsel sinizm boyutları arasında duygusal sinizm en düşük ortalama değere sahipken (Ort:2,539); en yüksek değer (Ort:3,296) bilişsel sinizme aittir. Değişkenlere ilişkin korelasyon katsayılarını incelediğimizde ise; algılanan iş güvencesizliğinin içsellik statüsü ile negatif $(\mathrm{r}=-, 678 ; \mathrm{p}=0,00)$; bilişsel, duygusal ve davranışsal sinizm ile de pozitif yönde ilişkili olduğu görülmektedir (sırasıyla; $r=, 644 ; \mathrm{r}=, 492 ; \mathrm{r}=, 418 ; \mathrm{p}<0,01$ ). Bunun yanı sıra, örgütsel sinizmin tüm alt boyutları içsellik statüsü ve örgütsel destek ile negatif yönde ilişkili iken algılanan örgütsel destek içsellik statüsü ile pozitif yönde ilişkilidir $(r=, 704 ; p=0,00)$. 
Araştırma hipotezlerinin testi için regresyon analizi gerçekleştirilmiştir. Regresyon analizine geçmeden önce gerekli ön koşulların (örneklem büyüklüğü, normal dağılım, doğrusallık) sağlanıp sağlanmadığı kontrol edilmiş; elde edilen sonuçlar doğrultusunda ön şartların sağlandığı kanaatine varılımıştır. Katılımcılara ilişkin kategorik niteliğinde olan demografik değişkenler kontrol grubu olarak belirlenmiş ve kukla değişkenlere dönüştürülerek analize dahil edilmiştir. Elde edilen sonuçlar Tablo 3'de yer almaktadır:

Tablo 3. Hiyerarşik Regresyon Analizi Sonuçları

\begin{tabular}{|c|c|c|c|c|c|c|c|c|}
\hline & \multicolumn{2}{|c|}{ İçsellik Statüsü } & \multicolumn{2}{|c|}{ Bilişsel Sinizm } & \multicolumn{2}{|c|}{ Duygusal Sinizm } & \multicolumn{2}{|c|}{ Davranışsal Sinizm } \\
\hline & Beta & S.H & Beta & S.H & Beta & S.H & Beta & S.H \\
\hline Sabit & ,493 &, $223 * *$ &,- 071 & ,231 &,- 565 &, $231 *$ & ,127 & 275 \\
\hline Yaş &,- 064 &, 063 &, 025 & ,063 &, 103 & ,063 &, 158 & 059 \\
\hline Cinsiyet &,- 248 &, $102 *$ &,- 040 & 103 & ,342 &, $103 * * *$ &,- 282 & $122 *$ \\
\hline Medeni Durum &,- 079 & ,072 & ,069 & 067 &, 063 &, 059 &, 026 &, 021 \\
\hline Eğitim &, 226 & 169 &,- 152 &, 101 &,- 012 &, 074 &,- 079 &, 112 \\
\hline Çalışma Süresi & ,007 & ,069 &,- 028 & ,068 &,- 076 &, 068 &,- 055 & ,080 \\
\hline Algılanan iş güvencesizliği &,- 689 &, $047 * * *$ & ,653 &, $049 * * *$ & ,509 &, $063 * * *$ & ,429 &, $057 * * *$ \\
\hline İçsellik statüsü & & &,- 328 &, $064 * * *$ &,- 590 &, $064 * * *$ &,- 278 &, $076 * *$ \\
\hline $\mathrm{R} / \Delta \mathrm{R}^{2}$ & & & & $5 /, 057$ & &, 183 & & $1 /, 041$ \\
\hline
\end{tabular}

Tablo 3'de yer alan regresyon katsayılarına baktığımızda; katılımcılara ilişkin demografik değişkenlerden bir tek cinsiyetin içsellik statüsü ve sinizm üzerinde anlamlı etkiye sahip olduğu görülmektedir. Buna göre, kadınlar erkeklere kıyasla daha az içsellik statüsüne sahip olmakla birlikte $(B=-, 248 ; p<0,05)$; duygusal sinizm düzeyleri daha yüksek $(B=, 342 ; p<0,001)$; davranışsal sinizm düzeyleri ise daha düşüktür $(B=-, 282 ; p<0,05)$. Algılanan iş güvencesizliğinin içsellik satüsünü negatif ( $\mathrm{B}=-, 689 ; \mathrm{p}<0,001)$; bilişsel, duygusal ve davranışsal sinizmi de pozitif yönde etkilediği görülmektedir (sırasıla; $\mathrm{B}=, 653 ; \mathrm{p}<0,001 ; \mathrm{B}=, 509 ; \mathrm{p}<0,001 ; \mathrm{B}=, 429 ; \mathrm{p}<0,001$ ). Dolayısıyla; H1a, H1b, H1c ve H2 hipotezleri desteklenmektedir. Bunun yanı sıra, içsellik statüsünün bilişsel $(B=-, 328 ; \mathrm{p}<0,001)$; duygusal ( $\mathrm{B}=-, 590$; $\mathrm{p}<0,001)$ ve davranışsal sinizme $(B=-, 278 ; p<0,01)$ de negatif yönde etki ettiği görülmektedir.

İçsellik statüsünün aracılık etkisine sahip olup olmadığı PROCESS Macro 2.16 Model 4 aracılığıyla incelenmiş ve bootstrapping yöntemi kullanılmıştır. Elde edilen sonuçlara göre, içsellik statüsünün algılanan iş güvencesizliği- duygusal sinizm $(\mathrm{CI}=$ \%95; BootLLCI=,2919, BootULCI=,5371; Boot $\mathrm{SE}=, 0627)$; algılanan iş güvencesizliği-davranışsal sinizm $(\mathrm{CI}=$ \%95; BootLLCI=,0685, BootULCI=,3128; Boot $\mathrm{SE}=, 0624)$ ve son olarak algılanan iş güvencesizliği-bilişsel sinizm ilişkisinde aracılık etkisinin anlamlı olduğu tespit edilmiştir $(\mathrm{CI}=\%$ 95; BootLLCI=,1255, BootULCI=,3389; Boot $\mathrm{SE}=$,0541). Bir diğer ifadeyle, içsellik statüsünün algılanan iş güvencesizliği ile örgütsel sinizmin tüm alt boyutları arasında aracılık etkisine sahip olduğu tespit edilmiştir. Dolayısıyla; H3a, H3b ve H3c hipotezleri desteklenmiştir.

Algılanan örgütsel desteğin; iş güvencesizliği-içsellik statüsü ve iş güvencesizliği-örgütsel sinizmin alt boyutları arasında düzenleyici etkiye sahip olup olmadığını belirlemek üzere etkileşim terimleri oluşturulmuş ve regresyon analizine dahil edilmiştir. Elde edilen sonuçlar Tablo 4'te yer almaktadır: 
Seçkin, Ş., N. / Journal of Yasar University, 2018, 13/50, 112-124

Tablo 4. Örgütsel Desteğin Düzenleyici Etkisine İlişkin Yapılan Hiyerarşik Regresyon Analizi Sonuçları

\begin{tabular}{|c|c|c|c|c|c|c|c|c|}
\hline & \multicolumn{2}{|c|}{ İçsellik Statüsü } & \multicolumn{2}{|c|}{ Bilişsel Sinizm } & \multicolumn{2}{|c|}{ Duygusal Sinizm } & \multicolumn{2}{|c|}{ Davranışsal Sinizm } \\
\hline & Beta & S.H & Beta & S.H & Beta & S.H & Beta & S.H \\
\hline Sabit & ,312 & ,205* &, 050 & ,047 &,- 495 & ,228** & ,289 & ,274 \\
\hline Yaş &,- 060 &, 055 &,- 066 &, 078 &, 095 &, 063 & ,138 &, 075 \\
\hline Cinskiyet &,- 248 &, $102 *$ &,- 040 & 103 &, 155 & , 102 &,- 169 &, $123 * *$ \\
\hline Medeni Durum &,- 143 & ,090 & 059 & ,037 & ,342 & , 103 &, 018 &, 051 \\
\hline Eğitim & ,212 & , 119 &,- 132 &, 121 & ,076 & ,068 &,- 092 & 073 \\
\hline Çalışma Süresi &, 050 &, 060 &, 061 &, 052 &,- 071 &, 068 &,- 056 & ,082 \\
\hline İçsellik statüsü & & &,- 618 &, $050 * * *$ &,- 659 &, $047 * * *$ &,- 440 &, $056 * * *$ \\
\hline Algılanan iş güvencesizliği &,- 399 &, $056 * * *$ & ,416 &, $064 * * *$ &, 128 &, $063 *$ & ,222 &, $076^{* *}$ \\
\hline Algılanan örgütsel destek & ,408 &, $057 * * *$ &,- 731 &, $057 * * *$ &,- 236 &, $080 * * *$ &,- 163 &, $079 *$ \\
\hline Alg. iş güvencesizliğiXörgütsel destek &, 111 &, $045^{*}$ &, 075 &, 051 &,- 190 &, $050 * * *$ &, 110 &, 060 \\
\hline $\mathrm{R} / \mathrm{R}^{2}$ & \multicolumn{2}{|c|}{, $770 /, 592$} & \multicolumn{2}{|c|}{, $840 /, 706$} & \multicolumn{2}{|c|}{,714/,510 } & \multicolumn{2}{|c|}{, $522 /, 272$} \\
\hline
\end{tabular}

Tablo 4’te yer alan bulgulara baktığımızda, algılanan örgütsel desteğin sadece algılanan iş güvencesizliği-içsellik statüsü ilişkisinde düzenleyici bir etkiye sahip olduğu ve katılımcıların içsellik statüsü algılamaları kontrol edildiğinde; örgütsel desteğin sadece algılanan iş güvencesizliği-duygusal sinizm arasında olası bir düzenleyici etkiye sahip olduğu görülmektedir. Dolayısıyla; H4 ve H5b hipotezleri desteklenmekte ancak H5a ve H5c hipotezleri reddedilmektedir.

Algılanan iş güvencesizliğinin içsellik statüsü ve duygusal sinizmle ilişkisinin büyük ölçüde algılanan örgütsel desteğe bağlı olup olmadığını belirlemek üzere basit eğim testi (Aiken ve West, 1991) yapılmış; algılanan örgütsel desteğin +1SS ve -1SS değerlerinde regresyon katsayıları hesaplanmıştır. Elde edilen sonuçlara göre; örgütsel destek algısı düşük olan çalışanlarda, algılanan iş güvencesizliğinin içsellik statüsü üzerindeki olumsuz etkisinin daha yüksek $(B=-, 510 ; p<, 001)$; örgütsel destek alg1sı yüksek olan çalışanlarda ise bu etkinin daha düşük olduğu $(B=-, 288 ; p<, 001)$ olduğu görülmüştür.

Bunun yanı sıra; yapılan basit eğim testi sonuçlarına göre, algılanan içsellik statüsü kontrol edildiğinde; örgütsel destek algısı düşük olan çalışanlarda; algılanan iş güvencesizliği arttıkça duygusal sinizmin pozitif yönde etkilendiği $(B=$ ,216; p=,015); ancak örgütsel destek algısı yüksek olan çalışanlarda algılanan iş güvencesizliğinin duygusal sinizm üzerinde anlamlı bir etkisinin olmadığı görülmüştür $(B=-, 135 ; p=, 077)$.

Algılanan iş güvencesizliğinin örgütsel sinizm üzerindeki dolaylı etkisinde örgütsel desteğin anlamlı bir farklılaşmaya yol açıp açmadığı PROCESS Macro 2.16 Model 8 kullanılarak incelenmiştir. Elde edilen sonuçlar Tablo 5 'te yer almaktadir:

Tablo 5. Algılanan İş Güvencesizliğinin Bilişsel, Duygusal ve Davranışsal Sinizm Üzerindeki Koşullu Dolaylı Etkisi

\begin{tabular}{|c|c|c|c|c|c|c|}
\hline \multirow{3}{*}{ Örgütsel Destek } & \multicolumn{2}{|c|}{ Bilişsel Sinizm } & \multicolumn{2}{|c|}{ Duygusal Sinizm } & \multicolumn{2}{|c|}{ Davranışsal Sinizm } \\
\hline & $\begin{array}{c}\text { Koşullu } \\
\text { Dolaylı } \\
\text { Etki }\end{array}$ & $\begin{array}{c}\% 95 \\
\text { Bootstrap CI }\end{array}$ & $\begin{array}{c}\text { Koşullu } \\
\text { Dolaylı } \\
\text { Etki }\end{array}$ & $\begin{array}{c}\% 95 \\
\text { Bootstrap CI }\end{array}$ & $\begin{array}{c}\text { Koşullu } \\
\text { Dolaylı } \\
\text { Etki }\end{array}$ & $\begin{array}{c}\% 95 \\
\text { Bootstrap CI }\end{array}$ \\
\hline & & LLCI ULCI & & LLCI ULCI & & LLCI ULCI \\
\hline Çok Düşük & ,0229 & $-0507,1192$ & ,2492 & , 1177, 4327 &, 1434 & ,0228, 2921 \\
\hline Düşük & 0189 & -,0414, 0890 & 1967 & 0967, 3289 &, 1132 & ,2241 \\
\hline Orta & 0155 & -,0351, 0715 & 1617 & 0792, 2758 & ,0931 & 0146 \\
\hline Yüksek & 0127 & -,0294, 0591 &, 1326 & 0595, 2405 & 0763 & 0138 \\
\hline Çok Yüksek &, 0116 & -,0267, 0558 &, 1209 & 0491, 2292 &, 0696 &, 1631 \\
\hline
\end{tabular}

Tablo 5'te yer alan sonuçlar incelendiğinde; algılanan iş güvencesizliğinin duygusal ve davranışsal sinizm üzerindeki dolaylı etkisinin katılımcıların algıladığı örgütsel destek düzeyi arttıkça değiştiği ve bu değişimin istatistiki açıdan anlamlı olduğu görülmektedir [CI:95\%: (duygusal sinizm: BootLLCI=,1177 BootULCI=,2292); (davranışsal sinizm: BootLLCI=,0228 BootULCI=,1631)]. Algılanan iş güvencesizliği arttıkça içsellik statüsü azalmakta; içsellik statüsünün azalmasıyla birlikte örgüte yönelik sinik duygu ve davranışlar da artmaktadır. Ancak sinik duygu ve davranışlardaki bu artış, algılanan örgütsel destek arttıkça giderek zayıflamaktadır. Bilişsel sinizmde ise istatistiki açıdan anlamlı bir değişim 
görülmemektedir (CI:95\%;BootLLCI=-,0507 BootULCI=,0558). Katılımcıların algıladığı örgütsel destek her ne düzeyde olursa olsun; iş güvencesizliğinin bilişsel sinizm üzerindeki dolaylı etkisi istatistiki açıdan anlamlı bir farklılaşma göstermemektedir.

\section{SONUÇ}

Elde edilen sonuçlar incelendiğinde; algılanan iş güvencesizliğinin içsellik statüsü ve örgütsel sinizmin tüm alt boyutları üzerinde pozitif bir etkisinin olduğu görülmektedir. Bir diğer ifadeyle çalışanlarda iş güvencesizliği algısı arttıkça hem örgüte olan aidiyet duyguları (içsellik statüsü algıları) hem de örgüte karşı sinik duygu, tutum ve davranışları da artmaktadır. Bunun yanı sıra; içsellik statüsünün, algılanan iş güvencesizliği-örgütsel sinizm ilişkisinde aracı bir etkiye sahip olduğu görülmektedir. Bir diğer ifadeyle, katılımcıların yaşadıkları iş güvencesizliği arttıkça örgüte olan aidiyet duyguları azalmakta ve bu da örgüte yönelik sinik duygu, düşünce ve davranışları da tetiklemektedir.

Algılanan örgütsel desteğin düzenleyici rolüne ilişkin elde edilen sonuçlar incelendiğinde ise; örgütsel desteğin algılanan iş güvencesizliği-içsellik statüsü ilişkisinin kuvvet derecesini farklılaştırdığı görülmektedir. İş güvencesizliği algısına sahip olan ancak yüksek düzeyde örgütten destek gördüğünü düşünen çalışanlarda yaşadıkları iş güvencesizliğinin içsellik statüsü algıları üzerindeki olumsuz etkisi daha düşüktür. Düşük düzeyde örgütten destek gördüklerini düşünen çalışanlarda ise bu olumsuz etki daha fazladır. Ayrıca, çalışanların algıladıkları içsellik statüsü kontrol edildiğinde;yaşadıkları iş güvencesizliği arttıkça örgüte yönelik sinik duygularının da arttığı ancak bu durumun örgütsel destek algısı düşük olan çalışanlarda daha güçlü olduğu görülmüştür.

Yapılan analizler sonucunda, örgütsel desteğin; algılanan iş güvencesizliğinin duygusal ve davranışsal sinizm üzerindeki dolaylı etkisinde de düzenleyici bir rol oynadığı tespit edilmiştir. Algılanan örgütsel destek arttıkça; algılanan iş güvencesizliğinin duygusal ve davranışsal sinizm üzerindeki dolaylı etkisinin giderek zayıfladığı görülmektedir. Bir diğer ifadeyle; algılanan iş güvencesizliği arttıkça içsellik statüsü azalmakta; içsellik statüsünün azalmasıyla birlikte duygusal ve davranışsal sinizm de artmaktadır. Ancak duygusal ve davranışsal sinizmdeki bu artış çalışanların algıladığ 1 örgütsel destek arttıkça giderek zayıflamaktadır.

Elde edilen bulgular değerlendirildiğinde; algılanan iş güvencesizliğinin katılımcıların hem kuruma karşı hissetikleri aidiyet duygusunu hem de örgüte yönelik tutum ve davranışlarını olumsuz yönde etkilediği ifade edilebilir. Türk toplumunda belirsizlikten kaçınma eğiliminin yüksek olması (Sargut, 2001) ve işten elde edilen gelirin pek çok çalışanın yaşamındaki temel gelir kaynağı olduğu dikkate alındığında, elde edilen sonuçların beklenen yönde olduğu söylenebilir. Algılanan iş güvencesizliği her ne kadar öznel bir yargı olsa da örgütsel çevreye ilişkin faktörlerden etkilenmekte ve çalışanın hem örgüte hem de işe yönelik tutum ve davranışlarını olumsuz yönde etkilemektedir. Dolayısıyla, yöneticilerin çalışanlar nezdinde oluşabilecek iş güvencesizliği algısını ve olası olumsuz sonuçlarını dikkate alması gerektiği söylenebilir. Örgüt içinde çok yönlü, açık ve şeffaf bir iletişim ortamının sağlanması; örgüt yönetimi ve üyeleri arasında güvene dayalı bir ilişkinin tesis edilmesi, çalışanlarda hem iş güvencesizliği algısını azaltacak hem de algılanan iş güvencesizliğinin olası olumsuz sonuçlarını asgari düzeye indirecektir. Araştırma bulgularının da gösterdiği üzere, bu süreçte örgütsel desteğin önemli bir role sahip olduğu söylenebilir. Çalışanların örgüte yaptıkları katkıların takdir edilmesi; örgüt için önemli ve değerli olduklarının hissettirilmesi; bir diğer ifadeyle çalışanlara örgütsel destek verilmesi önemlidir. İşe ilişkin stres faktörlerinin (iş yükü, rol belirsizliği ve rol çatışması vb.) ortadan kaldırılması çalışanlara kendilerini geliştirme ve kariyerde ilerleme fırsatlarının sağlanması; kurum içinde etkin bir performans değerlendirme ve ödüllendirme sistemininin yürülüğe konularak sağlıklı bir şekilde işlemesine azami özen gösterilmesi; beklentilerin üzerinde performans gösteren çalışanların ödüllendirilmesi; çalışanların örgütsel süreç ve işleyişlere ilişkin bilgilendirilmesi ve karar verme süreçlerine katılımlarının sağlanması; çalışanlar nezdinde örgütsel destek algısını artıracak pratik uygulamalara örnek olarak verilebilir. Örgütün çalışanlara verdiği destek arttıkça çalışanların kuruma olan aidiyet duygularının pekişeceği; mevcut işlerinin devamlılığına ilişkin kaygı yaşasalar bile kendilerini daha az dışsal olarak konumlandıracakları; dolayısıyla da örgüte yönelik daha az sinik duygular besleyecekleri söylenebilir.

Elde edilen bulguların ilgili yazına katkı sağlayacağı söylenebilir ancak araştırmanın bir takım kısıtları da mevcuttur. $\mathrm{Bu}$ araştırma kesitsel bir çalışma olup; veriler tek bir zaman diliminde toplanmıştır. Dolayısıyla, araştırma sonuçları ilişkisel nitelikte olup değişkenler arasında herhangi bir neden-sonuç ilişkisi kurulamamaktadır. Algılanan iş güvencesizliği her ne kadar bu çalı̧̧mada içsellik statüsünü negatif; örgütsel sinizmi de pozitif yönde etkileyen bağımsız değişken olarak ele alınsa da; çalışanların çeşitli sebeplerle örgüte yönelik besledikleri sinik tutumları arttıkça çalışanların hem örgüt içinde kendilerini daha fazla dışsal olarak konumlandırabilecekleri (içsellik statüsü algılarının azalacağı) hem de iş güvencesizliği algılarının artabileceği de düşünülebilir. İş güvencesizliği algısını tetikleyen çok çeşitli faktörler olmasına rağmen (bireysel, örgütsel ve sektöre ilişkin faktörler), örgütsel sinizmin iş güvencesizliği algısına etki eden olası bir etmen olabileceği ya da ilgili değişkenler arasında karşılıklı bir etkileşimin var olabileceği de düşünülebilir. Dolayısıyla, konuya ilişkin gelecekte yapılacak boylamsal çalışmaların, değişkenler arasındaki ilişkileri neden-sonuç kapsamında ele alınmasına imkan vermesi açısından önemli olduğu söylenebilir. Bunun yanı sıra, saha araştırması, sadece Malatya ilinde faaliyet gösteren orta ve büyük ölçekli imalat işletmelerinde idari birimlerde çalışan personel üzerinde 
Seçkin, Ş., N. / Journal of Yasar University, 2018, 13/50, 112-124

yürütüldüğünden; elde edilen bulgular genelleştirilememektedir. Katılımcıların önemli bir kısmının gıda sektöründe çalışıyor olması nedeniyle de elde edilen veriler sektörel açıdan birbiriyle karşılaştırılamamıştır; dolayısıyla kullanılan kolayda örneklem yönteminin araştırmanın bir diğer kısıtı olduğu ifade edilebilir. Konuya ilişkin bundan sonra yapılacak çalışmalarda sektörel karşılaştırmaların yapılması ve anlamlı farklılıkların olup olmadığının tespit edilmesinin ilgili alana önemli katkı sağlayabileceği ifade edilebilir. Ayıca, algılanan iş güvencesizliğini önemli ölçüde etkileyebilecek bir diğer faktör olan işletmedeki insan kaynakları politikaları ile lider-üye etkileşiminin gelecekte yapılacak çalışmalarda araştırma modeline dahil edilmesi konuya daha geniş bir perspektif kazandırması açısından araştırmacılara önerilebilir. 


\section{KAYNAKÇA}

Abraham, R.(2000). “Organizational Cynicism: Bases and Consequences”. Genetic, Social, and General Psychology Monographs, 126(3), 269-292.

Aiken, L. S., West, S.G.(1991). Multiple regression: Testing and interpreting interactions. Newbury Park:Sage.

Andersson, L. M.(1996). "Employee Cynicism: An Examination Using a Contract Violation Framework", Human Relations, Vol.19, Issue 11, 1395-1418

Andersson, L. M., Bateman, T. S. (1997). "Cynicism in the workplace: Some causes and effects", Journal of Organizational Behavior, Vol.18, 449-469.

Armstrong-Stassen, M., Schlosser, F.(2011). "Perceived organizational membership and the retention of older workers", Journal of Organizational Behavior, Vol.32, 319-344.

Ashford, S. J., Lee, C., Bobko, P.(1989). "Content, Causes, and consequences of job insecurity: A theory-Based Measure and Substantive Test", Academy of Management Journal, Vol.32, No.4, 803-829.

Ay, F.A.(2015). "İstismarcı Ynetim, İşyeri Yalnızlığıve Örgütsel Sinizm Arasındaki İlişkiler: Sağlık Çalışanlarına Yönelik Bir Çalışma”, Uluslararası Sosyal Araştırmalar Dergisi, Cilt.8, Sayı. 41, 116-1126

Blau, P.(1964). Exchange and power in social life, New York:Free Press.

Brandes, P., Dharwadkar, R., Dean, J. W.(1999). "Does Organizational Cynicism Matter? Employee and Supervisor Perspectives on Work Outcomes", Eastern Academy of Management Proceedings, 150-153.

Brandes, P., Castro, S., L., James, M. S. L., Martinez, A., D., Ferris, G.R., Hochwarter, W. A.(2008). "The Interatice Effects of Job Insecurity and Organizational Cynicism on Work Effort Following a Layoff', Journal of Leadership \& Organizational Studies, Vol.14, No.3, 233-247.

Buonocorea, F., Russob, M., Ferrarac, M.(2015). "Work-family conflict and job insecurity: are workers from different generations experiencing true differences?", Community, Work \& Family, Vol.18, No.3, 299-316.

Byrne, Z., Hocwarter, W. A.(2008)."Perceived organizational support and performance: Relationships across levels of organizational cynicism”, Journal of Managerial Psychology, Vol.23, 54-72.

Chen, Z. X., Aryee, S.(2007). "Delegation and employee work outcomes: An examination of the cultural context of mediating process in China", Academy of Management Journal, Vol.50, 226-238.

Cheng, G. H. L., Chan, D. K. S. (2008). "Who suffers more from job insecurity? A meta-analytic review", Applied Psychology: An International Review, Vol.57, No.2, 272-303.

Chirumbolo, A., Hellgren, J.(2003). "Individual and organizational consequences of job insecurity: A European Study", Economic and Industrial Democracy, Vol.24, No.2, 217-240.

Chiaburu, D. S., Peng, A. C., Oh, I.S., Banks, G. C., Lomeli, L.C. (2013). “Antecedents and consequences of employee organizational cynicism: A meta-analysis”, Journal of Vocational Behavior, Vol.83, 181-197.

Costa, S., Neves, P.(2017). "Job insecurity and work outcomes: The role of psychological contract breach and positive psychological capital”, Work \& Stress, 1-20.

Çakal, M., Özdemir, Y.(2016). Acil Sağlık Hizmetleri Çalışanlarının Algılanan Aidiyet Durumları. Süleyman Demirel Üniversitesi Vizyoner Dergisi, Cilt.7, Say1.14, 105-118.

Çınar, O., Karcıoğlu, F., Aslan, F.(2014).“The relationships among organizational cynicism, job insecurity and turnover intention: A survey study in Erzurum/Turkey”. Procedia-Social and Behavioral Sciences, Vol.150, 429-437.

Davy, J., A., Kinicki, A., J., Scheck, C., L.(1991). Developing and testing a model of survivor responses to layoffs", Journal of Vocational Behavior, Vol.38, No.3, 302-317.

De Cuyper, N., Makikangas, A., Kinnunen, U., Mauno, S., De Witte, H.(2012). "Cross-lagged associations between perceived external employability, job insecurity, and exhaustion: Testing gain and loss spirals according to the Conservation of Resources Theory", Journal of Organizational Behavior, Vol.33, 770-788.

De Witte, H.(2005). "Job insecurity: review of the international literature on definitions, prevalence, antecedents and consequences", SA Journal of Industrial Psychology, Vol.31, No.4, 1-6.

Dean, J. W., Brandes, P., Dharwadkar, R.(1998). "Organizational Cynicism”, Academy of Management Review, Vol.23, No.2, 341-352.

Dekker, S. W. A., Schaufeli, W. B.(1995). "The effects of job insecurity on psychological health and withdrawal: A longitudinal study", Australian Psychologist, Vol.30, 57-63.

Eisenberger, R., Huntington, R., Hutchison, S., Sowa, D.(1986). "Perceived organizational support”, Journal of Applied Psychology, Vol.71, 500-507.

Giray, M. D., Şahin, D. N.(2012). Algılanan Örgütsel, Yönetici ve Çalışma Arkadaşları Desteği Ölçekleri, Türk Psikoloji Yazilar1, 15(30), 1-9.

Gouldner, A.W.(1960). “The norm of reciprocity: A preliminary statement”. American Sociological Review, Vol.25, 161178.

Greenhalgh, L., Rosenblatt, Z.(1984). “Job Insecurity: Toward conceptual clarity”, Academy of Management Review, Vol.3, 438-448.

Johnson, J., O’Leary-Kelly, A.M.(2003). "The effects of psychological contract breach and organizational cynicism: not all social exchange violations are created equal”, Journal of Organizational Behavior, Vol.24, 627-647 
Karacaoğlu, K., İnce, F.(2012). Brandes, Dharwadkar ve Dean'in (1999) Örgütsel Sinizm Ölçeği Türkçe Formunun Geçerlilik ve Güvenilirlik Çalışması: Kayseri Organize Sanayi Bölgesi Örneği, Business and Economics Research Journal, Vol.3, No.3, 77-92

Keim, A. C., Landis, R. S., Pierce, C. A., Earnest, D. R.(2014). "Why do employees worry about their jobs? A metaanalytic review of predictors of job insecurity", Journal of Occupational Health Psychology, Vol.19, No.3, 269290

Kinnunen, U., Mauno, S., Natti, J., Happonen, M.(2000), “Organizational antecedents and outcomes of job insecurity: a longitudinal study in three organizations in Finland”, Journal of Organizational Behavior, Vol.21, 443-459.

Klandermans, B., Hesselink, J. K., Vuuren, T. V.(2010). "Employment status and job insecurity: On the subjective appraisal of an objective status", Economic and Industrial Democracy, Vol.31, No.4, 557-577.

Knapp, J. R., Smith, B. R., Sprinkle, T. A.(2014). "Clarifying the relational ties of organizational belonging: Understanding the roles of perceived insider status, psychological ownership, and organizational identification”, Journal of Leadership \& Organizational Studies, Vol.21, 273-285.

Köksal, O.(2012). Sosyal Değişim Teorisi Çerçevesinde Güven ve Algılanan Aidiyet Durumunun Örgütsel Vatandaşlık Davranışı ve Saldırgan Davranışlar Üzerine Etkisi. Doktora Tezi, Erciyes Üniversitesi Sosyal Bilimler Enstitüsü

Kurtessis J., N., Eisenberger, R., Ford, M. T., Buffardi, L. C., Steward, K. A., Adis, C. S.(2017). "Perceived Organizational Support: A Meta-Analytic Evaluation of Organizational Support Theory", Journal of Management, Vol.43, No.6, 1854-1884.

Lapalme, M., Stamper, C. L., Simard, G., Tremblay, M.(2009). "Bringing the outside in: Can "external" workers experience insider status?", Journal of Organizational Behavior, Vol.30, 919-940.

Lastad, L., Berntson, E., Naswall, K. ve Sverke, M.(2014). "Do core self-evaluations and coping style influence the perception of job insecurity?", European Journal of Work and Organizational Psychology, Vol.23, No.5, 680692

Loi, R., Lam, L. W., Chan, K. W.(2012). “Coping with Job Insecurity: The Role of Procedural Justice, Ethical Leadership and Power Distance Orientation", Journal of Business Ethics, Vol.108, 361-372.

Masterson, S. S., Stamper, C. L. (2003). "Perceived organizational membership: An aggregate framework representing the employee-organization relationship", Journal of Organizational Behavior, Vol.24, No.5, 473-490.

Meydan, C. H., Şeşen, H. (2015). Yapısal Eşitlik Modellemesi: AMOS Uygulamaları. Detay Yayıncıllk, 2.basım, Ankara.

Mirap, S. O.(2008). Algılanan Aidiyet Durumunun Görev Performansı, Bağlamsal Performans ve Toplam Performansa Etkilerini Ölçmeye Yönelik Özel Sağlık Kurumlarında Bir Araştırma. 16. Yönetim ve Organizasyon Kongresi (16-18 Mayıs), İstanbul.

Önder, Ç., Wasti, A. S.(2002). "İş güvencesi endeksi ve iş güvencesi memnuniyeti ölçeği: güvenilirlik ve geçerlik analizi”, Yönetim Araştırmaları Dergisi, Cilt.2, No.1, 23-47.

Özdevecioğlu, M., Balcı, F.(2011). "Algılanan İçsellik Statüsünün Örgütsel Vatandaşlık Davranışı Üzerindeki Etkisi”, Erciyes Üniversitesi İktisadi ve İdari Bilimler Fakültesi Dergisi, Say1.37, 41-64.

Probst, T. M.(2000). "Wedded to the job: Moderating effects of job involvement on the consequences of job insecurity", Journal of Occupational Health Psychology, Vol.5, 63-73.

Probst, T. M.(2005). "Countering the negative effects of job insecurity through participative decision-making: Lessons from the demand-control model”, Journal of Occupational Health Psychology, Vol.10, No.4, 320-329.

Probst, T.M.(2003). "Development and validation of the Job Security Index and the Job Security Satisfaction Scale: A Classical Theory and IRT Approach". Journal of Occupational and Organizational Psychology, Vol.76, 451-467.

Pugh, S.D., Skarlicki, D.P., Passell, B.S.(2003). "After the fall: Layoff victims'trust and cynicism in re-employment", Journal of Occupational and Organizational Psychology, Vol.76, 201-212.

Rhoades, L., Eisenberger, R.(2002). "Perceived Organizational Support: A Review of the Literature", Journal of Applied Psychology, Vol.87, No.4, 698-714.

Robinson, S. L. (1996). "Trust and breach of the psychological contract. Administrative science quarterly", Vol.41, 574599.

Rousseau, D. M.(1989). "Psychological and implied contracts in organizations", Employee Responsibilities and Rights Journal", Vol.2, p.121-139.

Sargut S. A.(2001). Kültürler Arası Farklılaşma ve Yönetim. İmge Kitabevi, 2.basım,Ankara

Stamper, C. L., Masterson, S. S.(2002). "Insider or outsider? How employee perceptions of insider status affect their work behavior.", Journal of Organizational Behavior, Vol.23, No.8, 875-894.

Sverke, M., Hellgren, J., Naswall, K. (2002). "No security: A meta-analysis and review of jobinsecurity and its consequences", Journal of Occupational Health Psychology, Vol.7, No.3, 242-264.

Vander Elst, T., Van den Broeck, A., De Cuyper, N., De Witte, H.(2014). "On the reciprocal relationship between job insecurity and employee well-being: Mediation by perceived control?", Journal of Occupational and Organizational Psychology, Vol.87, 671-693.

Wang, J., Kim, T.(2013). "Proactive socialization beahvior in China: The mediating role of perceived insider status and the moderating role of supervisors' traditionality", Journal of Organizational Behavior, Vol34, 389-406. 
Seçkin, Ş., N. / Journal of Yasar University, 2018, 13/50, 112-124

Wang, L., Chu, X., Ni, N. (2010). "Leader-member exchange and organizational citizenship behavior: A new perspective from perceived insider status and Chinese traditionality", Frontiers of Literary Studies in China, Vol.4, No.1, 148-169. 